\title{
THE ROWETT RESEARCH INSTITUTE FOR ANIMAL NUTRITION GOLDEN JUBILEE
}

$\mathrm{T}$ HIS year the Rowett Institute celebrates its origin in 1913, when a Joint Committee of the University of Aberdeen and the North of Scotland College of Agriculture was formed for the prosecution of research in animal nutrition. The late Prof. E. P. Cathcart, who in 1913 was a lecturer in the Institute of Physiology in the University of Glasgow, was first approached and accepted the offer to go to Aberdeen to start this research work. Later, he decided to take a chair of physiology in the University of London and, when intimating his change of mind, recommended that Dr. John B. Orr be offered the post. Thus, Dr. Orr became the first director of what not long after grew into the scale of an institute, and in this capacity he served until his retirement in 1945, when he was succeeded by Dr. D. P. Cuthbertson, also from the Institute of Physiology, Glasgow, but who had been seconded at the time to the Medical Research Council. During its fifty years, therefore, the Institute has had only two directors.

The Governing Body of the Institute is now tripartite, with five persons appointed by each of the following: University of Aberdeen, North of Scotland College of Agriculture and the Secretary of State for Scotland. The Principal and Vice-Chancellor of the University is its chairman.

Following his retirement in 1945, Sir John Orr became the first director-general of the Food and Agriculture Organization of the United Nations. The need for the creation of such an organization owed much to Orr's vision and his previous researches culminating in his book Food, Health and Income. Orr had also been responsible for a large-scale demonstration of the nutritive value of milk for children, and the evidence from this and comparable trials was largely responsible for the introduction of the milk and finally the meals-in-schools scheme. He had felt that so much useful knowledge had been acquired about animals that it was time it was applied to man himself.

The Commonwealth Bureau of Animal Nutrition does not share the Jubilee that the Rowett Institute is celebrating: it is only thirty-two years old, but, as in some ways an offshoot of the Institute, it shares its history and celebration, for Orr was its first director, followed in more recent years by Dr. I. Leitch and Dr. D. Harvey. The present director of the Institute is consultant director to the Bureau and editor-in-chief of its publication, Nutrition Abstracts and Reviews.
The early and subsequent history of the Institute, its Reid Library, its farm - the Duthie Experimental Stock Farm-and its residential hall-Strathcona Club-are described in a unique volume entitled Progress in Nutrition and Allied Sciences, which is edited by the present director and published by Oliver and Boyd at the modest price of $50 s$. for its 452 pages (Nature, 200, 201; 1963). This provides an account of the present resoarch work of the Institute in relation to the existing state of knowledge, and some account is also woven into it of the past research of the Institute. A few distinguished ex-members of staff have contributed topics not at present being investigated at the Institute. There are thirty-nine chapters. Among the significant topics dealt with are those which have been in recent years the continuing concern of the Institute. These are the physiology, biochemistry and microbiology of digestion, particularly in the ruminant; the nutritional significance of the 'non-protein nitrogen' fraction of plants; physiological individuality; minerals in relation to the skeleton, the teeth and functioning of the nervous system; mammalian glycosidases and their inhibition; growth and reproduction; family diets; infection and resistance. The Institute's present contribution to our better understanding of the nutrition of dairy cattle, shoop and their shelter, poultry and pigs and the recent system for intensive beef production introduced in Britain by the Institute are also described. The Institute continues to assist in defining where the application of man's scientific knowledge of agriculture to world needs can best be directed.

The present staff of the Institute numbers two hundred and fifty persons, of whom some fifty-five belong to the scientific officer class. Dr. R. L. M. Synge, Nobel prizeman, is probably its most distinguished member of staff. He has written a challenging article on the state of our ignorance concerning the nutritional role of the constituents of the non-protein fraction of plants at this point in time.

The Institute publishes each year an annual report which is free to universities, colleges and non-commercial research organizations.

At its Founders' Day Dinner in this year of its Golden Jubilee, the Secretary of State for Scotland, the Right Hon. Michael Noble, gave the principal speech and proposed a toast to "The Founders".

D. P. Cuthbertson

\section{VEGETATION OF THE HUMID TROPICS}

\begin{abstract}
A SYMPOSIUM on the vegetation of the Humid Tropics was hold at Kuching, Sarawak, during July 2-10; it was sponsored jointly by the South-east Asia Science Co-operation Office of Unesco and the Government of Sarawak, and was attended by some 36 participants coming from most of the countries of Southeast Asia, as well as from Europe, the United States and Australia. The United States was represented by Dr. F. R. Fosberg of the Pacific Vegetation Project, Washington, chairman of the Humid Tropies Committee of Unesco, and by Dr. George Gillett of the University of Hawaii; participants from the United Kingdom were Sir George Taylor, director of the Royal Botanic Gardens, Kew, Mr. P. Greig-Smith, reader in botany at the University College of North Wales, Bangor, and Prof. P. W. Richards. Mr. L. Mattsson, director of the South-east
\end{abstract}

Asia Office at Djakarta, was the official representative of Unesco. This symposium was the third of a series on tropical vegetation organized by the South-east Asia Office of Unesco and followed those held at Tjiawi, Java, in 1958, and at Goroka, New Guinea, in 1960 (see Nature, 189,$24 ; 1961$ ).

The present policy of the South-east Asia Science Co-operation Office is that each symposium should have one or more principal themes, as well as giving exports on tropical vegetation the opportunity of discussing their work and problems with colleagues whom of necessity they cannot meet very often. At the Goroka symposium, the Proceedings of which have recently been published *,

- Unesco Science Co-operation Office for South-east Asia and Administration of the Territory of Papua and New Guinea (Government Printer, Canberra, 1963). 
the emphasis was on the impact of man on the vegetation of the humid tropics. At the recent symposium at Kuching the chief themes were recent advances in tropical ecology and the application of quantitative methods to the study of tropical vegetation. Although according to the programme the latter topic was the subject of only one morning's session, it was in fact a recurrent theme, both in the regular sessions and in the less formal, but no less animated, discussions 'out of hours'. The papers presented to the symposium indeed covered a wide field, from the "Entropy Concept in Ecology" (F. R. Fosberg) to the "Ecology of Pitcher Plants (Nepenthes)" (B. E. Smythios), and provided a cross-section of the main fields of activity in present-day tropical ecology.

Sir Alexander Waddell, Governor of Sarawak, declared the symposium open at an inaugural session in the afternoon of July 2, under the chairmanship of Mr. B. E. Smythies, conservator of forests, Sarawak. In his speech the Governor stressed the importance of ecological research to a country such as Sarawak, much of which consists of undeveloped land covered with forest and other vegetation in a rolatively natural state. He also quite rightly directed attention to the considerable contribution to research on tropical vegetation which is being made by the staff of the Sarawak Forest Department.

The one session devoted entirely to quantitative methods was opened by Mr. P. Greig-Smith, who strongly emphasized the importance of statistically reliable sampling procedures and directed attention to some of the pitfalls which surround attempts to apply quantitative methods of description and analysis to plant communities as rich in species and lacking in homogeneity as the forests of the humid tropies; he also discussed the problems involved in the selection and delimitation of sample plots. The type of quantitative method to be used must be modified, $\mathrm{Mr}$. Greig-Smith considered, to suit both the nature of the vegetation to be studied and the ultimate object in view. This opening paper led to a long and lively discussion in which many modern techniques such as 'plotless sampling', gradient analysis, etc., were considered.

This paper was followed by two others dealing with related problems. Dr. P. S. Ashton gave an account of his work (shortly to be published as an Oxford Forestry Memoir) on the Mixed Dipterocarp forests of Brunei. The forests of this small country-no larger than an English county-are extraordinarily rich in species; there are more than 150 species of large trees belonging to the family Dipterocarpaceae alone. Dr. Ashton has, however, successfully used a modification of Bray and Curtis's ordination technique and shown that the varying composition of the forest community reflects very sensitively the innumerable small variations in topography, soil and local climate. This paper high-lighted the extreme complexity of some plant communities of the humid tropics, but also gave reason for hoping that relatively simple quantitative techniques might prove adequate in providing a firm basis for correlating the endless and seemingly random variations of forest composition with the factors of environment. The last paper in this session was read by Mr. A. J. Vincent of the Forest Research Institute, Kepong, Federation of Malaya, and was entitled "Tropical Rain Forest Ecology: What Does the Forester Need to Know About It and How Should He Put the Necessary and Sufficient Knowledge on a Quantitative Basis?" As might be guessed from its title this paper was valuable in bringing the somewhat acadomic approach to tropical ecology which had prevailed earlier in the discussion into relation with practical realities in the nowly independent countries of south-east Asia at the present day.

Quantitative problems of other kinds were raised in several other papers, notably in ono by Mr. D. I. Nicholson of the Sabah (North Borneo) Forestry Department on "Studies in Virgin Forest Near Sandakan, North Borneo".
Among the many interesting problems raised in the discussion on this paper was the reliability of the various methods at present used for estimating the age of rain forest trees (which do not as a rule produce annual growth rings). Mr. I. M. Qureshi (Dehra Dun) expressed the view that quantitative ecological methods should be, so far as possible, standardized as well as statistically valid.

Another subject with which several papers were concerned and which led to much informal discussion was the relation between vegetation, soil and parent rock. Dr. L. J. Webb, of the University of Queensland, in a paper on the rain forests of north-eastern Australia, directed attention to the well-known fact that in the humid tropical regions of Australia there is a marked difference between the vegetation on basalt and on other parent materials such as sandstone, the former bearing rain forest similar in many of its features to the rain forests on the Indo-Malayan region, the latter eucalypt forests of a characteristically Australian type. In spite of this obvious difference in vegetation, however, soil analysis, at least using conventional methods, does not seem to reveal any marked differences in nutrient elements such as phosphorus, potassium and nitrogen between the soils formed from basalt and those derived from other parent materials. A similar problem was discussed by Prof. Richards in a paper dealing with soil conditions in somo lowland forest communities in Brunei and Sarawak, where there are striking differences between the 'Heath forest' on the sandy kerangas (podsolic) soils and the Mixed Dipterocarp forests on soils of the more normal latosol type. Here again the soils are obviously different and are clearly correlated with differences of vegetation, but the soil analyses appear to indicate very little significant difference in the amount of nutrients present in the soil. The very distinctive character of 'Heath forest' communities was also brought out in a paper by $\mathrm{Mr}$. Anwari Dilmy (Herbarium Bogoriense) dealing with the vegetation of the Sampit area in Central Kalimantan (Indonesian Borneo).

It was worthy of note that although nearly every contribution to the symposium was concerned with the ecology of plant communities rather than with autecology, several speakers stressed the need for more work, especially experimental work, on the ecology of individual species. Some sessions ranged into widely different fields, for example, one of the most interesting and informative dealt with palynology, a subject of great promise for the future understanding of tropical vegetation. Dr. D. Walker of the Research School of Pacific Studies, Australian National University, Canberra, gave an account of his work on the stratigraphy of a swamp in the New Guinea highlands, and Mr. J. Mullor, of Brunei-Shell Petroleum Co., summarized the results of his fascinating work on the pollen in Holocene peats in Sarawak. In Borneo, a complete stratigraphical sequence from the Cretaceous to the present day is available for pollen analysis. This has already revealed much of interest about the history of the mangroves and peat swamp, but what has already been discoverod can be no more than a foretaste of results of immense significance for the understanding of the vegetation of south-east Asia.

A paper by Mr. T. Smitinand on the vegetation of a limestone massif in Thailand and another by Dr. J. A. R. Anderson on the limestone habitat in Sarawak providod much now information on a very interesting type of tropical habitat which has hitherto received very littlo attention and also raised the issue of conservation which, though not one of the official themes of the symposium, was clearly one of the underlying anxieties of most participants. The vegetation of the fantastically shaped limestone hills in Sarawak, Malaya, Thailand and elsewhere in south-east Asia is of the greatest interest to the botanist because of its strange and often endemic plant species, but there is a grave danger that because of the high economic value of limestone for making cement and 
other purposes, especially in relatively advanced countries such as the Federation of Malaya, the habitat will be destroyed before there is any adequate scientific knowledge of its flora and fauna. Similar anxieties were expressed about several other types of tropical vegetation, especially the lowland rain forest of the Malay Peninsula and the montane forests of Mount Kinabalu in North Borneo where the proposal to establish a national park needs to be pressed forward rapidly before the steady advance of shifting cultivation destroys any more of the forest vegetation.

Not the least important part of the activities of the symposium were the field excursions, which gave the opportunity for very valuable discussions of present-day problems in tropical ecology. The week at Kuching was interrupted by a very pleasant and interesting visit to the Bako National Park and Santubong Mountain at the mouth of the Sarawak River. The excellent living accommodation and well-designed paths at Bako gave the party an opportunity of seeing something of the unusual forest and heath-like plant communities on a low sandstone plateau on the coast, where Nepenthes and strange-looking epiphytic species of Dischidia and Hydnophytum grow in abundance and can readily be studied. Santubong at the mouth of the Sarawak river, memorable for its associations with Alfred Russell Wallace, provided a glimpse of the extraordinary variety of species and plant communities on a steep and isolated mountain less than 3,000 ft. high. Beforo leaving Kuching, members of the symposium were able to see the excellent 'natural' arboretum created by the Sarawak Forest Department in the Semengoh Forest Reserve and climb the 100 -ft. tower which is being used to collect data on temperature and humidity at different levels in undisturbed dipterocarp forest. On the same day a short visit was paid to the famous limestone hills at Bau.

After the conclusion of the activities of the symposium in Sarawak, most of the participants were able to take part in a tour to Brunei, where one day was spent in studying the vegetation of the peat swamps and another in the magnificent Mixed Dipterocarp forest of the Andulau Forest Reserve. After this many of the party joined in a short visit to Sabah (North Borneo) and climbed Kinabalu $(13,455 \mathrm{ft}$.) with its amazingly rich montane flora.

The success of the symposium owed much to the careful preparatory work of Dr. J. A. R. Anderson and other mombers of the Sarawak and Sabah Forest Departments, as well as to the simple, but very convenient, accommodation provided by the Sarawak Government at the Batu Lintang Teachers' Training College. The fact that it is possible to hold such a symposium at all underlines the increasing importance of tropical ecology. The foundation of a Society for Tropical Ecology in India, the formation of a Tropical Group in the British Ecological Society and the series of symposia sponsored by Unesco since the inauguration of its Humid Tropics Committes at Kandy in 1956, show that this interest is widespread and that an appreciation is developing of what ecology can contribute to scientific knowledge in a part of the world where most of the major problems are biological. P. W. RICHards

\section{ACTIVATION ANALYSIS IN MEDICINE AND BIOCHEMISTRY}

A CTIVATION analysis is a sensitive and versatile technique for the determination of trace constituents through measurement of the radioactivity induced after bombardment by neutrons or other sub-atomic particles. First suggested by Hevesy and Levi in 1936, it became practicable on a useful scale with the development of nuclear reactors and other neutron sources after the Second World War. A rapid growth of interest in biological applications was made evident during the third International Biological Colloquium, organized by the Commissariat à l'Energie Atomique and held at Saclay, near Paris, during September 26 28. The gathering of 150 research workers, drawn from many countries and many disciplines, heard 20 papers on recent developments and potential applications of the method in medicine and biochemistry.

Interest was equally divided between the experimental techniques and their applications. Discussion of techniques was concentrated on three major problems: $(a)$ sources; (b) chemical manipulation of samples; (c) assay of induced radioactivity.

Thermal neutron activation is serviceable for the estimation of about 70 elements at sub-microgram levels. Consequently, the nuclear reactor is widely used as a source; most of the research reactors brought into opera. tion in recent years, giving fluxes of $10^{11}-10^{12} \mathrm{n} / \mathrm{cm}^{2} / \mathrm{sec}$, are contributing to analytical research projects. A reactor is, however, not always essential or even desirable. For some elements the sensitivity of activation analysis using thermal neutrons is very low; for a few elements (near the beginning and end of the Periodic Table) the method is not applicable at all. Even when adequate sensitivity is available, interfering activities may be contributed by other elements present in the sample under examination. The estimation of manganese in blood can, for example, be achieved by using the reaction ${ }^{55} \mathrm{Mn}(\mathrm{n}, \gamma)^{56} \mathrm{Mn}$. The small flux of fast neutrons inside a typical reactor will generate the same product by the reaction ${ }^{56} \mathrm{Fe}(\mathrm{n}, \mathrm{p})^{56} \mathrm{Mn}$, giving an error of as much as
30 per cent. In this instance, a correction can be calculated, but the interference is sometimes of a more subtle kind, not so easily dealt with.

It is occasionally possible to secure greater sensitivity and accuracy by using fast neutrons. The most convenient source is a discharge-tube generator in which a tritium target is bombarded by deuterons accelerated to energies of $150-200 \mathrm{keV}$. Several models of neutron generators using this principle are available commercially, giving 14-MeV neutrons at fluxes of $10^{7}-10^{9} \mathrm{n} / \mathrm{cm}^{2} / \mathrm{sec}$. W. Schulze (Free University of Berlin) discussed the use of fast neutrons in activation analysis and gave a comprehensive table of nuclear cross-sections (calculated and measured) for $(n, \gamma),(n, p),(n, 2 n)$ and $(n, \alpha)$ reactions. J. Wood (Services Electronic Research Laboratory, Baldock) reported new developments in the design of discharge tubes for the $(d, t)$ reaction; with the further advances now in prospect, this work should make the use of laboratory neutron generators more attractive in terms of initial cost and tube life.

The use of charged particles for activation was exemplified in a report by A. Fleckenstein (University of Freiburg) on the determination of oxygen in biological materials, using the stable isotope oxygen-18 in the reaction ${ }^{18} \mathrm{O}(\mathrm{p}$, n) ${ }^{18} \mathrm{~F}$, which gives excellent sensitivity. Recognition of the potentialities of activation analysis with protons or helium-3 ions has led to renewed interest in the cyclotren; it is hoped that a machine giving $8-\mathrm{MeV}$ protons can be produced commercially in the United States for 100,000 dollars.

The rest of the discussion on techniques was concerned with the relative contributions of radiochemical manipulation and of instrumental assay. Broadly speaking, the activity under investigation may be separated chemically (using modifications of normal analytical procedures) or physically (by examination of tho $\gamma$-ray spectrum of the induced radioactivity). In practice it is not always possible to ashieve complete separation by either method aione. In biological materials, for example, the presence 